\title{
TUBULAR REABSORPTION OF PHOSPHATE IN THE DOG ${ }^{1,2}$
}

\author{
BY PAUL K. SMITH, ROBERT W. OLLAYOS, AND ALEXANDER W. WINKLER \\ (From the Department of Internal Medicine and the Laboratory of Pharmacology, Yale \\ University School of Medicine, New Haven)
}

(Received for publication July 30, 1942)

Harrison and Harrison (1) have recently claimed that "under standard conditions there is a limiting maximal rate of reabsorption of phosphate by the renal tubules which does not vary when the concentration of phosphate in plasma is elevated by the administration of phosphate salts." They believe that this phenomenon is analogous to the limiting maximal rate of tubular reabsorption of glucose and other sugars, first demonstrated by Shannon and Fisher (2). The existence of such a maximal rate of tubular reabsorption has not been demonstrated for any other ion ( 3 , 4), so that, if Harrison and Harrison are correct, the behavior of phosphate is probably unique. Before accepting this conclusion, it seemed wise to study the excretion of phosphate over a wider range of phosphate concentration in serum than did Harrison and Harrison. The experiments reported here also permit certain other observations on the excretion of phosphate.

\section{MATERIALS AND METHODS}

Adult female dogs were used throughout. Creatinine solution, 10 grams per $100 \mathrm{cc}$., was injected intraperitoneally at the beginning of each experiment. The exact experimental procedure has been previously described (3). Catheterized urine was collected before and in successive periods after the infusion of neutral isotonic sodium phosphate solution. Blood specimens were obtained at the beginning and at the end of each collection period. Mean serum concentrations and clearances were calculated according to the method of Winkler and Parra (5). Inorganic phosphate was determined by the method of Fiske and Subbarow (6), creatinine by a modification of the method of Folin (7). Anaerobic ultrafiltrates of serum were prepared by the method of Lavietes (8). Creatinine clearance is assumed to be identical with glomerular filtration rate in the dog (9).

1 Part of the material in this paper is drawn from a thesis submitted by Robert W. Ollayos to the Yale University School of Medicine in partial fulfillment of the requirements for the degree of Doctor of Medicine, 1941.

2 Aided by grants from the Ella Sachs Plotz Fund, the Emerson Fund, and the Fluid Research Fund of the Yale University School of Medicine.

\section{RESULTS}

The results in four experiments following the injection of isotonic neutral sodium phosphate mixtures are recorded in Table I. The method of calculation is that of Harrison and Harrison (1). Rate of glomerular filtration for each period is calculated by multiplying together creatinine clearance and mean concentration of phosphate in serum. The rate of tubular reabsorption is then measured by the difference between this rate of filtration through the glomeruli and the final rate of excretion in the urine. Obviously, the rate of reabsorption steadily increases as concentration rises, so that over the range studied there is not even a suggestion of any "maximal" rate of reabsorption. This is true in spite of the fact that the serum concentration was raised to much higher levels than those attained in the experiments of Harrison and Harrison. Indeed, two of the four animals later developed tetany, and died within twelve hours following the infusions of phosphate, suggesting that the levels reached in our experiments approached the limits of physiological tolerance. The highest value for tubular reabsorption reported by Harrison and Harrison was about $3.50 \mathrm{mgm}$. per minute. However, rates of reabsorption three and four times this supposed "maximum" are found in the experiments of Table I.

Serum inorganic phosphate concentrations were used directly in the calculations of the rate of glomerular filtration of phosphate in Table I. Implicit in this procedure is the assumption that the concentration of phosphate in glomerular filtrate is equal to that in serum. The justification of this assumption appears in Table II, in which the concentrations of phosphate in ultrafiltrates of plasma (using cellophane membranes) are compared with the concentrations of phosphate in serum water, in three out of four of the experiments of Table I. Evidently an inconsiderable fraction only of the phosphate of serum is not 
TABLE I

Intravenous injection of neutral isotonic sodium phosphate solutions

\begin{tabular}{|c|c|c|c|c|c|c|c|c|c|c|}
\hline \multirow{2}{*}{$\begin{array}{l}\text { Experiment } \\
\text { number } \\
\text { Dog weight }\end{array}$} & \multirow[b]{2}{*}{ Period* } & \multirow{2}{*}{ Duration } & \multirow[b]{2}{*}{$\begin{array}{l}\text { Urine flow } \\
\text { (1) }\end{array}$} & \multicolumn{2}{|c|}{ Phosphate } & \multicolumn{2}{|c|}{ Clearance } & \multicolumn{3}{|c|}{ Amount of phosphate } \\
\hline & & & & $\underset{\text { (2) }}{\text { Urine }}$ & $\underset{(3)}{\text { Serumt }} t$ & PO. & $\begin{array}{c}\text { Creatinine } \\
\text { (4) }\end{array}$ & $\begin{array}{l}\text { Filtered } \\
\frac{(3) \times(4)}{100}\end{array}$ & $\begin{array}{l}\text { Excreted } \\
\frac{(1) \times(2)}{100}\end{array}$ & $\frac{\begin{array}{l}\text { Reabsorbed } \\
\text { (3) } \times(4)-(1) \times(2)\end{array}}{100}$ \\
\hline kgm. & & minutes & $\begin{array}{l}c c \text { per } \\
\text { minute }\end{array}$ & \multicolumn{2}{|c|}{ mgm. per cent } & \multicolumn{2}{|c|}{ cc. per minute } & \multicolumn{3}{|c|}{ mgm. per minute } \\
\hline 1. 20.5 & $\begin{array}{l}1 \\
2 \\
3 \\
4\end{array}$ & $\begin{array}{r}38 \\
60 \\
85 \\
155\end{array}$ & $\begin{array}{l}0.92 \\
0.60 \\
0.44 \\
0.26\end{array}$ & $\begin{array}{l}589 \\
703 \\
740 \\
686\end{array}$ & $\begin{array}{l}14.7 \\
13.4 \\
12.6 \\
10.7\end{array}$ & $\begin{array}{l}37 \\
32 \\
26 \\
17\end{array}$ & $\begin{array}{l}77 \\
69 \\
51 \\
28\end{array}$ & $\begin{array}{r}11.32 \\
9.25 \\
6.43 \\
3.00\end{array}$ & $\begin{array}{l}5.42 \\
4.23 \\
3.22 \\
1.78\end{array}$ & $\begin{array}{l}5.90 \\
5.02 \\
3.21 \\
1.22\end{array}$ \\
\hline 2. 15.0 & $\begin{array}{l}1 \\
2 \\
3 \\
4\end{array}$ & $\begin{array}{l}35 \\
68 \\
65 \\
63\end{array}$ & $\begin{array}{l}3.72 \\
1.40 \\
0.80 \\
0.78\end{array}$ & $\begin{array}{l}235 \\
291 \\
292 \\
266\end{array}$ & $\begin{array}{l}40.0 \\
25.0 \\
18.5 \\
16.6\end{array}$ & $\begin{array}{l}22 \\
16 \\
13 \\
13\end{array}$ & $\begin{array}{l}54 \\
31 \\
25 \\
23\end{array}$ & $\begin{array}{r}21.60 \\
7.75 \\
4.63 \\
3.82\end{array}$ & $\begin{array}{l}8.73 \\
4.05 \\
2.33 \\
2.08\end{array}$ & $\begin{array}{r}12.87 \\
3.70 \\
2.30 \\
1.74\end{array}$ \\
\hline 3. 13.2 & $\begin{array}{l}1 \\
2 \\
3 \\
4 \\
5\end{array}$ & $\begin{array}{l}26 \\
29 \\
28 \\
57 \\
66\end{array}$ & $\begin{array}{l}3.85 \\
2.31 \\
1.43 \\
0.79 \\
0.50\end{array}$ & $\begin{array}{l}391 \\
377 \\
384 \\
429 \\
474\end{array}$ & $\begin{array}{l}34.5 \\
21.0 \\
16.8 \\
13.5 \\
10.0\end{array}$ & $\begin{array}{l}44 \\
41 \\
33 \\
25 \\
24\end{array}$ & $\begin{array}{l}90 \\
87 \\
81 \\
59 \\
70\end{array}$ & $\begin{array}{r}31.00 \\
18.27 \\
13.60 \\
7.96 \\
7.00\end{array}$ & $\begin{array}{r}15.05 \\
8.71 \\
5.49 \\
3.39 \\
2.37\end{array}$ & $\begin{array}{r}15.95 \\
9.56 \\
8.11 \\
4.57 \\
4.63\end{array}$ \\
\hline 4. 17.6 & $\begin{array}{l}1 \\
2 \\
3 \\
4 \\
5 \\
6\end{array}$ & $\begin{array}{l}31 \\
21 \\
67 \\
82 \\
30 \\
25\end{array}$ & $\begin{array}{l}2.87 \\
1.76 \\
1.10 \\
0.65 \\
0.47 \\
0.36\end{array}$ & $\begin{array}{l}332 \\
276 \\
284 \\
403 \\
479 \\
549\end{array}$ & $\begin{array}{r}20.0 \\
12.5 \\
10.2 \\
8.5 \\
7.9 \\
7.5\end{array}$ & $\begin{array}{l}48 \\
39 \\
31 \\
31 \\
28 \\
26\end{array}$ & $\begin{array}{l}74 \\
80 \\
60 \\
48 \\
66 \\
68\end{array}$ & $\begin{array}{r}14.80 \\
10.00 \\
6.12 \\
4.08 \\
5.21 \\
5.10\end{array}$ & $\begin{array}{l}9.54 \\
4.86 \\
3.12 \\
2.62 \\
2.25 \\
1.98\end{array}$ & $\begin{array}{l}5.26 \\
5.14 \\
3.00 \\
1.46 \\
2.96 \\
3.12\end{array}$ \\
\hline
\end{tabular}

* Successive periods after the infusion.

ultrafilterable. Any colloidal complex of calcium and phosphate which might be formed is therefore quantitatively unimportant. If these concentrations in ultrafiltrate are substituted for concentrations in serum in the calculations of Table $I$; the estimated rates of reabsorption are only slightly altered.

TABLE II

Ultrafilterable inorganic phosphate of serum

\begin{tabular}{|c|c|c|c|c|}
\hline \multirow{2}{*}{$\begin{array}{l}\text { Experiment } \\
\text { number }\end{array}$} & \multirow{2}{*}{ Sample } & \multicolumn{2}{|c|}{ Phosphate } & \multirow{2}{*}{$\begin{array}{l}\text { Phosphate, } \\
\text { ultrafilterable }\end{array}$} \\
\hline & & Serum & Ultrafiltrate & \\
\hline 1 & $\begin{array}{l}1 \\
2 \\
3 \\
4 \\
5\end{array}$ & $\begin{array}{c}\text { mgm. per } \\
17.52 \\
14.44 \\
14.60 \\
12.83 \\
10.45\end{array}$ & $\begin{array}{c}\text { pcc. water } \\
17.40 \\
15.55 \\
15.55 \\
12.30 \\
10.48\end{array}$ & $\begin{array}{c}\text { per cent } \\
99 \\
108 \\
107 \\
96 \\
100\end{array}$ \\
\hline 3 & $\begin{array}{l}1 \\
2 \\
3 \\
4\end{array}$ & $\begin{array}{r}48.75 \\
19.84 \\
12.92 \\
8.93\end{array}$ & $\begin{array}{r}44.10 \\
19.28 \\
11.87 \\
7.69\end{array}$ & $\begin{array}{l}91 \\
97 \\
92 \\
86\end{array}$ \\
\hline 4 & $\begin{array}{l}1 \\
2 \\
3 \\
4\end{array}$ & $\begin{array}{r}33.95 \\
14.36 \\
9.93 \\
8.62\end{array}$ & $\begin{array}{r}30.93 \\
13.23 \\
9.24 \\
8.62\end{array}$ & $\begin{array}{r}93 \\
92 \\
93 \\
100\end{array}$ \\
\hline
\end{tabular}

$\dagger$ Interpolated values.

\section{DISCUSSION}

These experiments demonstrate that phosphate is reabsorbed by the tubules in a manner resembling that of other ions, rather than that of glucose and the other sugars. Harrison and Harrison were presumably led to a contrary, and erroneous, conclusion by studying variations in the reabsorption of phosphate over too narrow a range of concentration of phosphate in serum. In addition, the excretion of inorganic phosphate is related to its concentration in serum, and to its simultaneous glomerular filtration rate, in a manner resembling that of other ions. In Figure 1, the excretion rate of inorganic phosphate is plotted against concentration of inorganic phosphate in serum. Data from experiments of Pitts (10), in which hypertonic neutral phosphate solutions were injected, are included for comparative purposes. There is obviously a direct relationship between the two variables, and all the lines except that corresponding to experiment 2 (Table I) fall into the same rather narrow range. No differences are apparent between our experiments with 


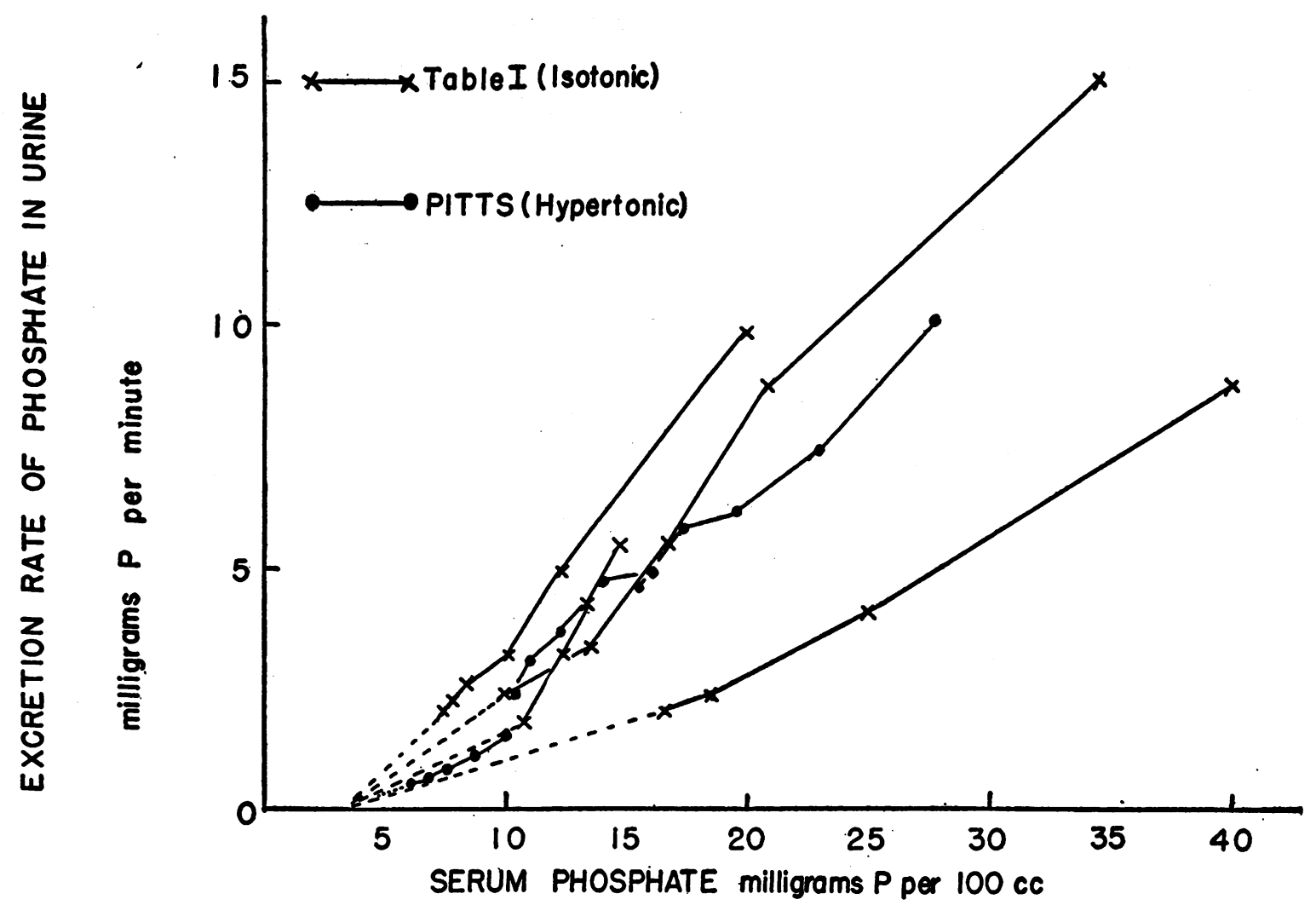

Fig. 1. Relationship Between Rate of Excretion of Inorganic Phosphate in Urine and Simultangous Concentration of Inorganic Phosphate in Serum

The solid lines represent exogenous excretion, the broken lines the transition to endogenous excretion.

isotonic sodium phosphate and those of Pitts with hypertonic sodium phosphate. Adolph (11) and Pitts (10), in discussing experiments with phosphate injection, have previously commented on the tendency of lines relating phosphate excretion to serum concentration to intersect the abscissa well above the origin, near a point approximating normal serum concentration. This is roughly true in our experiments, but on close examination it appears that the upper portion of the lines would not, if prolonged, cut the abscissa exactly at the endogenous point. Instead, the prolongations would intercept the abscissa well above the endogenous region. The lines representing the whole of phosphate excretion are therefore not exactly straight. The lower portions gradually curve as they join the point corresponding to endogenous excretion. This behavior is very similar to that of sulfate (3) and of potassium (4), and indicates that exogenous phosphate, like exogenous sulfate and potassium, is excreted according to another law than that governing excretion of the same ions at low endogenous levels.

Phosphate clearance is a function of serum concentration, being higher, the greater the serum concentration (Table I). This is a necessary consequence of the fact that the lines of Figure 1 do not pass through the origin, and is a characteristic feature of the clearances of a number of ions $(3,4)$. There is a rough correlation between phosphate clearance and creatinine clearance in Table I. Their ratio lies between 0.3 and 0.6. This tendency for the ratio to increase with rising serum concentration is less distinct than that of the ratio of phosphate to xylose clearance in the experiments of Pitts (10). The results are not, however, really inconsistent with his. The values for the ratio are also consistent with those obtained by Fay, Behrmann and Buck (12), who have compared phosphate and creatinine clearances directly. 


\section{CONCLUSIONS}

(1) No limiting or "maximal" rate of tubular reabsorption of inorganic phosphate in the dog could be demonstrated.

(2) In this respect, excretion of phosphate resembles that of other ions, rather than that of glucose.

(3) The relation of the excretion of phosphate to its concentration in serum and its relation to glomerular filtration are similar in character to those of sulfate and of potassium.

\section{BIBLIOGRAPHY}

1. Harrison, H. E., and Harrison, H. C., The renal excretion of inorganic phosphate in relation to the action of Vitamin D and parathyroid hormone. J. Clin. Invest., 1941, 20, 47.

2. Shannon, J. A., and Fisher, S., The renal tubular reabsorption of glucose in the normal dog. Am. J. Physiol., 1938, 122, 765.

3. Schwartz, B. M., Smith, P. K., and Winkler, A. W., Renal excretion of sulfate. Am. J. Physiol., 1942, $137,658$.
4. Winkler, A. W., and Smith, P. K., Renal excretion of potassium salts. Am. J. Physiol., 1942, 138, 94.

5. Winkler, A. W., and Parra, J., The measurement of glomerular filtration. The creatinine, sucrose and urea clearances in subjects without renal disease. J. Clin. Invest., 1937, 16, 859.

6. Fiske, C. H., and Subbarow, Y., The colorimetric determination of phosphorus. J. Biol. Chem., 1925, 66, 375.

7. Peters, J. P., and Van Slyke, D. D., Quantitative Clinical Chemistry. II. Methods. Williams \& Wilkins Co., Baltimore, 1931.

8. Lavietes, P. H., Anaerobic ultrafiltration. J. Biol. Chem., 1937, 120, 267.

9. Shannon, J. A., The excretion of inulin and creatinine at low urine flows by the normal dog. Am. J. Physiol., 1936, 114, 362.

10. Pitts, R., The excretion of urine in the dog. VII. Inorganic phosphate in relation to plasma phosphate level. Am. J. Physiol., 1933, 106, 1.

11. Adolph, E. F., The chemical sensitiveness of the kidneys. Am. J. Physiol., 1925, 74, 93.

12. Fay, M., Behrmann, V. G., and Buck, D. M., The parathyroids and the clearance of inorganic phosphate. Am. J. Physiol., 1942, 136, 716. 